\title{
PARTISIPASI MASYARAKAT DALAM MENGELOLA ALOKASI DANA DESA (ADD) DI DESA TEGESWETAN DAN DESA JANGKRIKAN KECAMATAN KEPIL KABUPATEN WONOSOBO
}

\author{
PARTICIPATION IN MANAGING \\ ALLOCATION FUND VILLAGE (ADD) TEGESWETAN VILLAGE AND VILLAGE \\ JANGKRIKAN DISTRICT DISTRICT KEPIL WONOSOBO
}

\author{
Ray Septianis Kartika \\ Badan Penelitian dan Pengembangan Kementerian Dalam Negeri \\ Jalan Kramat Raya No. 132, Senen - Jakarta Pusat \\ e-mail: raseka_twpa@yahoo.com
}

Diterima: 11 Juli 2012; direvisi: 31 Juli 2012; disetujui: 10 Agustus 2012

\begin{abstract}
Abstrak
Tujuan penelitian ini adalah untuk mengetahui partisipasi masyarakat dalam mengelola ADD dan mengidentifikasi faktor pendukung dan penghambat yang ditemui masyarakat dalam berpartisipasi mengelola ADD. Metode penelitiannya menggunakan deskriptif analitis kualitatif dengan informan kepala desa dan masyarakat. Hasil penelitian menyebutkan bahwa Masyarakat Desa Tegeswetan dan Desa Jangkrikan berinisiatif besar untuk berkontribusi dalam pengelolaan ADD. Tidak hanya dalam perencanaan, pelaksanaan maupun pengawasan, tetapi yang lebih penting adalah kesadaran masyarakat untuk terlibat dalam membangun desa merupakan solusi untuk memajukan pembangunan desa.

Kata kunci: partisipasi masyarakat, $\mathrm{ADD}$, pemerintah daerah, pembangunan desa.
\end{abstract}

\begin{abstract}
Purpose of this study was to determine the people's participation in managing ADD and identify supporting factors and obstacles encountered in participating communities to manage ADD.Method of research using qualitative descriptive analysis of village heads and community informants.The study saysthat the Rural Community and Rural JangkrikanTegeswetan major initiative to contribute to the management of ADD.Not justin the planning, implementation and monitoring, but more importantis the awareness of the community to get involvedin building the villageis a solution to promote rural development.
\end{abstract}

Keywords: community participation, ADD, local government, village development.

\section{PENDAHULUAN}

Desa sebagai sistem pemerintahan terkecil menuntut adanya pembaharuan guna mendukung pembangunan desa yang lebih meningkat dan tingkat kehidupan masyarakat desa yang jauh dari kemiskinan. Berbagai permasalahan yang ada di desa dan sangat kompleks, menjadikan batu sandungan bagi desa untuk berkembang. Mulai dari adanya urusan-urusan yang seyogyanya mutlak menjadi urusan desa, namun masih menjadi kewenangan pemerintah kabupaten sebagaimana yang tertuang dalam Undang-Undang No.32 Tahun 2004 tentang Pemerintah Daerah dan Peraturan Pemerintah No. 72 Tahun 2005 tentang Desa, hingga lahirnya sebuah Permendagri No. 30 Tahun 2006 tentang Tatacara Penyerahan Urusan Pemerintahan Kabupaten/Kota Kepada Desa. Proses penyerahan kewenangan tersebut memang sudah sepatutnya menjadi titik awal kebangkitan desa. Dimana desa diberikan kepenuhan mutlak untuk mengatur dan mengelola tata pemerintahnnya sendiri tanpa intervensi dari pihak manapun, tentunya dengan mengandalkan sumber daya manusia yang ada di desa sebagai subjek pelaksana pembangunan. Pelimpahan kewenangan kepada desa tersebut dapat menjadikan instrumen dan solusi yang tepat untuk mewujudkan akselerasi pembangunan di desa. Meskipun harus juga diimbangi dengan pendukung lainnya, seperti kemampuan dan mentalitas aparat pemerintah desa maupun sikap responsif masyarakat desa untuk secara konstruktif dan bertahap berupaya meningkatkan kesejahteraannya.

Atas dasar pertimbangan itulah, maka untuk menunjukkan eksistensi desa sebagai bagian dari pemerintahan langkah awalnya dengan memberikan kewenangan kepada desa untuk mengelola keuangannya sendiri melalui pemberian Alokasi Dana Desa (ADD) yang dilakukan oleh Pemerintah Daerah. Tujuannya adalah untuk memberikan ruang yang lebih besar bagi masyarakat desa agar dapat berperan aktif dalam penyelenggaraan pembangunan di desa. Pemberian ADD kepada desa karena didasari oleh beberapa kendala yang dihadapi desa, yang sebagian 
besar desa mengalami keterbatasan dalam keuangan desa, sehingga Program ADD adalah terobosan dalam upaya penyelenggaraan pemerintahan desa dan pemberdayaan masyarakat desa secara terpadu. Menurut Hudayana, ada empat faktor utama yang menyebabkan lahirnya ADD, yaitu: (1) desa memiliki APBDes yang kecil dan sumber pendapatannya sangat tergantung pada bantuan yang sangat kecil pula; (2) Kesejahteraan masyarakat desa rendah; (3) Rendahnya dana operasional desa untuk menjalankan pelayanan; dan (4) Banyak program pembangunan masuk ke desa, tetapi hanya dikelola oleh dinas.

ADD yang diberikan tersebut pada prinsipnya harus menganut prinsip akuntabel, transparansi, dan partisipasi maupun efisiensi menjadi agenda yang sangat penting. Pengelolaan keuangan desa yang diberikan kepada daerah melalui ADD pada prinsipnya tetap mengacu pada pokok pengelolaan keuangan daerah, yang dimaksudkan untuk membiayai program pemerintah desa dalam melaksanakan kegiatan pemerintahan dan pemberdayaan masyarakat. Meskipun besaran dana ADD masih terbilang terbatas, namun telah mampu menjadi stimulan bagi pelaksanaan pembangunan desa. Bahkan sebagian besar masyarakat desa menyampaikan opininya bahwa kebijakan ADD ini dirasakan lebih bermanfaat. Mekanismenya dirasakan lebih transparan dan partisipatif dan pemanfaatannya lebih demokratis, berdasarkan pada rembug desa, sebagaimana yang di langsir oleh sebuah situs internet.

Pemberian ADD kepada desa, juga dapat dijadikan cerminan terwujudnya good governance, dimana pemerintah dan masyarakat memiliki hubungan yang erat dan sekaligus meningkatkan partisipasi masyarakat, sehingga mendorong akuntabilitas, transparansi dan responsivitas pemerintah lokal. Hal senada diungkapkan Haryanto (2007) pada sebuah situs internet, bahwa prinsipprinsip good governance, diantaranya adalah partisipasi masyarakat, tegaknya supremasi hukum, tumbuhnya transparansi yang dibangun atas dasar arus informasi yang bebas dan informasi perlu dapat diakses oleh pihak-pihak yang berkepentingan dan memadai, peduli pada stakeholder, berorientasi pada konsensus, kesetaraan, efektifitas dan efisiensi, akuntabilitas, serta adanya visi strategis.

Lebih lanjut dikemukakan, bahwa nilai yang terpenting dalam pemberian ADD adalah dana yang diperuntukkan bagi kemaslahatan masyarakat desa, secara etis harus pula melibatkan masyarakat sebagai sasaran fundamental kemajuan desa. Masyarakat dipandang sebagai elemen yang terpenting dalam proses pembangunan, apalagi kita sadari percepatan pembangunan harus dimulai dari bottom up, yaitu mengerakkan masyarakat agar berperan aktif dalam memajukan pembangunan. Titik sentral pembangunan memang terlihat dari partisipasi aktif masyarakatnya. Berkeinginan merubah dan memiliki keinginan untuk dirubah, merupakan aset terpenting untuk memberdayakan masyarakat. Beberapa alasan mengapa masyarakat perlu diajak untuk berperan serta dan didorong untuk berpartisipasi, sebagaimana yang ditulis Rahardjo Adisasmita (2006), yaitu (1) Masyarakat memahami sesungguhnya tentang keadaan lingkungan sosial dan ekonomi masyarakatnya; (2) Masyarakat mampu menganalisis sebab dan akibat dari berbagai kejadian yang terjadi dalam masyarakat; (3) Masyarakat mampu merumuskan solusi untuk mengatasi permasalahan dan kendala yang dihadapi masyarakat; (4) Masyarakat mampu memanfaatkan sumber daya pembangunan (SDA, SDM, dana, teknologi) yang dimiliki untuk meningkatkan produksi dan produktivitas dalam rangka mencapai sasaran pembangunan masyarakatnya; dan (5) Masyarakat dengan upaya meningkatkan kemampuan SDM-nya dan kemauan, sehingga dengan berlandaskan pada kepercayaan diri dan keswadayan yang kuat mampu menghilangkan sebagian besar ketergantungan terhadap pihak luar.

Dengan demikian penulis memandang sangat esensialnya menyoroti dan menguak partisipasi masyarakat dalam pengelolaan ADD. Asumsinya adalah bahwa partisipasi masyarakat selain sebagai upaya mempercepat pembangunan desa, namun juga dapat dilihat sebagai upaya terwujudnya demokratisasi desa.

Menilik uraian di atas dapat ditarik perumusan masalah yang dianggap sangat penting untuk kita amati, yaitu: (1) Bagaimana partisipasi masyarakat dalam mengelola ADD, dan (2) Faktor pendukung dan penghambat apa saja yang ditemui masyarakat dalam berpartisipasi mengelola ADD.Dari perumusan masalah tersebut, maka tujuan penelitian ini adalah (1) Mengetahui proses partisipasi masyarakat dalam mengelola ADD; (2) Mengidentifikasi faktor pendukung dan penghambat yang ditemui masyarakat dalam berpartisipasi mengelola ADD.

Teori yang relevan dalam penelitian ini adalah Good Governance, di manasalah seorang pakar, Hetifah Sj. Sumarto (2003) mengatakan bahwa "Salah satu karakteristik dari good governance atau tata kelola pemerintahan yang baik atau kepemerintahan yang baik adalah partisipasi." Selanjutnya, UNDP mengartikan partisipasi sebagai karakteristik pelaksanaan good governance adalah keterlibatan masyarakat dalam pembentukan keputusan, baik secara langsung maupun tidak langsung melalui lembaga perwakilan yang dapat menyalurkan aspirasinya. Partisipasi tersebut dibangun atas dasar kebebasan bersosialisasi dan berbicara serta berpartisipasi secara konstruktif.

Sebagai wujud menciptakan kepemerintahan yang baik, maka harus tertuju pada seluruh aspek khususnya pada pembangunan pedesaan partisipatif. Pembangunan masyarakat desa pada dasarnya merupakan gerakan masyarakat yang didukung oleh pemerintah untuk memajukan masyarakat desa. Oleh karena itu, pendekatan utama yang digunakan dalam 
pembangunan masyarakat desa adalah, sebagai berikut: (a) Pendekatan partisipatif yang melibatkan warga masyarakat desa dalam segenap proses pembangunan, mulai dari perencanaan, pelaksanaan, pengendalian dan pemanfaatan hasil-hasilnya; (b) Pendekatan kemandirian yang menitikberatkan pada kegiatan dan usaha berdasarkan kemandirian lokal; (c) Pendekatan keterpaduan, yaitu mengarahkan kegiatan pembangunan secara lintas sektor dan lintas daerah ke dalam suatu proses pembangunan yang menyeluruh dan terpadu. Tujuan akhir dari pembangunan pedesaan adalah untuk meningkatkan kesejahteraan penduduknya secara langsung dan secara tidak langsung adalah untuk meletakkan dasar-dasar pembangunan yang kokoh untuk memperkuat pembangunan daerah dan pembangunan nasional sebagai tujuan antara atau sasaran dari pembangunan pedesaan adalah mengupayakan agar desa-desa yang merupakan satuan terkecil administrasi pemerintahan dapat mempercepat pertumbuhan tingkat keswadayaan. Menumbuh-kembangkan keswadayaan melalui Partisipasi Masyarakat, pandangan Schlippe (2007) suatu desa dapat berkembang baik terdapat tiga unsur yang merupakan suatu kesatuan yaitu desa, masyarakat dan pemerintahan desa. Dalam partisipasi masyarakat, pelaksanaan program pembangunan diperlukan kesadaran warga masyarakat akan minat dan kepentingan yang sama. Strategi yang bisa diterapkan adalah penyadaran. Untuk berhasilnya program tersebut warga masyarakat dituntut untuk terlibat tidak hanya dalam aspek kognitif dan praktis tetapi juga keterlibatan emosional. Berdasarkan pandangannya partisipasi dapat dilihat dari dua hal yaitu:

1. Partisipasi dalam perencanaan, dapat dilihat dari dua aspek posistif dan negatif. Pada segi positif, partisipasi adalah dapat mendorong munculnya keterlibatan secara emosional terhadap programprogram pembangunan desa yang telah direncanakan bersama. Sedangkan negatifnya adalah kemungkinan tidak dapat dihindarinya pertentangan antar kelompok dalam masyarakat yang dapat menunda atau bahkan menghambat tercapainya suatu keputusan bersama. Perencanaan secara partisipastif diperlukan karena bermanfaat yakni (1) Masyarakat mampu secara kritis menilai lingkungan sosial ekonominya dan mampu mengidentifikasi bidang-bidang atau sektor-sektor yang perlu dilakukan perbaikan, dengan demikian diketahui masa depan mereka, (2) Masyarakat dapat berperan dalam perencanaan masa depan masyarakatnya tanpa memerlukan bantuan para pakar atau instansi perencanaan pembangunan dari luar daerah pedesaan, (3) Masyarakat dapat menghimpun sumber daya dan sumber dana dari kalangan anggota masyarakat untuk mewujudkan tujuan yang dikehendaki masyarakat .
2. Partisipasi dalam pelaksanaan. Segi positifnya adalah program yang telah direncanakan dapat selesai dikerjakan. Tetapi segi negatifnya adalah cenderung menjadikan warga masyarakat sebagai objek pembangunan dimana warga hanya dijadikan pelaksana pembangunan tanpa didorong untuk mengerti dan menyadari permasalahan yang mereka hadapi. Sehingga warga masyarakat tidak secara emosional terlibat dalam program, yang berakibat kegagalan seringkali tidak dapat dihindari. Partisipasi masyarakat menurut Isbandi adalah keikutsertaan masyarakat dalam proses pengidentifikasian masalah dan potensi yang ada di masyarakat, pemilihan dan pengambilan keputusan tentang alternatif solusi untuk menangani masalah, pelaksanaan upaya mengatasi masalah, dan keterlibatan masyarakat dalam proses mengevaluasi perubahan yang terjadi. Mikkelsen (1999) membagi partisipasi menjadi 6 (enam) pengertian, yaitu (1) Partisipasi adalah kontribusi sukarela dari masyarakat kepada proyek tanpa ikut serta dalam pengambilan keputusan, (2) Partisipasi adalah "pemekaan" (membuat peka) pihak masyarakat untuk meningkatkan kemauan menerima dan kemampuan untuk menanggapi proyek-proyek pembangunan, (3) Partisipasi adalah keterlibatan sukarela oleh masyarakat dalam perubahan yang ditentukannya sendiri, (4) Partisipasi adalah suatu proses yang aktif, yang mengandung arti bahwa orang atau kelompok yang terkait, mengambil inisiatif dan menggunakan kebebasannya untuk melakukan hal itu, (5) Partisipasi adalah pemantapan dialog antara masyarakat setempat dengan para staf yang melakukan persiapan, pelaksanaan, monitoring proyek, agar supaya memperoleh informasi mengenai konteks lokal, dan dampakdampak sosial, (6) Partisipasi adalah keterlibatan masyarakat dalam pembangunan diri, kehidupan, dan lingkungan mereka. Sedangkan pentingnya partisipasi dikemukakan oleh Conyers sebagai berikut: pertama, partisipasi masyarakat merupakan suatu alat guna memperoleh informasi mengenai kondisi, kebutuhan, dan sikap masyarakat setempat, yang tanpa kehadirannya program pembangunan serta proyek-proyek akan gagal; kedua, bahwa masyarakat akan lebih mempercayai proyek atau program pembangunan apabila keberadaannya dilibatkan dalam proses persiapan dan perencanaan; ketiga, partisipasi merupakan suatu hak demokrasi bila masyarakat dilibatkan dalam pembangunan masyarakat mereka sendiri.

Pelibatan masyarakat dalam seluruh aspek pembangunan terutama di desa, secara prinsipil harus ditekankan pula keterlibatan mereka dalam Alokasi Dana Desa.Menurut Bahrul Ulum dalam kegiatan Bintek, Partisipasi masyarakat dalam mengelola ADD adalah hak bagi warga untuk menyuarakan, 
mengakses, mengontrol program ADD yang ada di desanya. Sedangkan dampak dari tingginya kepercayaan masyarakat terhadap program tersebut disebut swadaya. Kebijakan ADD sejalan dengan agenda Otonomi daerah, dimana desa ditempatkan sebagai basis desentralisasi. Kebijakan ADD sangat relevan dengan perspektif yang menempatkan desa sebagai basis partisipasi. Karena desa berhadapan langsung dengan masyarakat dan control masyarakat lebih kuat. Masih menurut Bahrul Ulum, cara membangun partisipasi ADD yaitu: (1) Sisi kelembagaan pembentukan pelaksana pengelolaan ADD melalui musyawarah; (2) Perencanaan melibatkan keterwakilan masyarakat dalam penyusunan APBDes secara partisipatif; dan (3) Penggunaan ADD sebaiknya sesuai aturan $70 \%$ untuk Belanja Pembangunan dan 30\% Belanja Rutin. Pada dasarnya pemberian ADD merupakan wujud dari pemenuhan hak desa untuk menyelenggarakan otonominya agar tumbuh dan berkembang mengikuti pertumbuhan dari desa itu sendiri berdasarkan keanekaragaman, partisipasi, otonomi asli, demokrasi dan pemberdayaan masyarakat. ADD merupakan hak desa yang berasal dari dana perimbangan pusat dan daerah yang mana pemerintah daerah kabupaten/kota memiliki hak untuk memperoleh anggaran DAU (Dana Alokasi Umum) dan DAK (Dana Alokasi Khusus) dari Pemerintah Pusat. Berdasarkan Permendagri No. 37 Tahun 2007 tentang Pedoman Pengelolaan Keuangan Desa dijelaskan pada Pasal 18 bahwa alokasi dana desa berasal dari APBD kabupaten/kota yang bersumber dari bagian dana perimbangan keuangan pusat dan daerah yang diterima oleh kabupaten/kota untuk desa paling sedikit 10\% (sepuluh persen). Tujuan Alokasi Dana Desa menurut PP No.72 Tahun 2005 tentang Desa untuk (1) Menanggulangi kemiskinan dan mengurangi kesenjangan; (2) Meningkatkan perencanaan dan penganggaran pembangunan di tingkat desa dan pemberdayaan masyarakat; (3) Meningkatkan pembangunan infrastruktur pedesaan; Meningkatkan pengamalan nilai-nilai kegamaan, sosial budaya dalam rangka mewujudkan peningkatan sosial; (5) Meningkatkan ketentraman dan ketertiban masyarakat; (6) Meningkatkan pelayanan pada masyarakat desa dalam rangka pengembangan kegiatan sosial dan ekonomi masyarakat; (7) Mendorong peningkatan keswadayaan dan gotong royong masyarakat; dan (8) Meningkatkan pendapatan desa dan masyarakat desa melalui Badan Usaha Milik Desa (BUMDes).

Dalam penelitian ini menggunakan metode deskriptif analitis. Menurut Suharsimi Arikunto (2003) penelitian deskriptif adalah penelitian yang tidak dimaksudkan untuk menguji hipotesis tertentu, tetapi hanya menggambarkan "apa adanya" tentang suatu variabel, gejala atau keadaan. Pendekatan yang digunakan dalam penelitian ini menggunakan pendekatan kualitatif. Wilayah dalam penelitian ini berada di Provinsi Jawa Tengah dengan mengambil lokasi di Kabupaten Wonosobo dikarenakan penyelewengan dana ADD pernah terjadi di Kabupaten Wonosobo. Informan dalam penelitian ini adalah masyarakat yang berada di lokus penelitian, yang berjumlah sekitar 5 informan yang terdiri dari masyarakat dan kepala desa. Pemilihan informan dengan menggunakan teknik snowball sampling. Dimana pada teknik ini peneliti mencari sumber informan yang akurat dengan menanyakan kepada informan lainnya yang dipandang dapat memberikan informasi yang dibutuhkan dalam penelitian ini. Sedangkan teknik pengumpulan data diperoleh dengan cara: (1) Observasi, dimana peneliti secara langsung mendatangi lokus penelitian sekaligus mengamati partisipasi masyarakat di lokasi tersebut. Observasi juga dianggap sebaga wahana yang tepat untuk menggali dan memperoleh informasi, karena peneliti mengetahui kondisi subyek yang ditelitinya; (2) Wawancara, dilakukan dengan mengkaji dan menggali informasi dari masyarakat dan kepala desa secara komprehensif dan seobyektif mungkin yang dilakukan peneliti secara maksimal dengan mengacu pada pedoman wawancara. Teknik analisis datanya adalah menggunakan analisis data kualitatif yaitu dengan menggambarkan, menguraikan dan menganalisis data berdasarkan hasil wawancara dan observasi lapangan. Informasi yang diterima oleh peneliti ditata, diedit, diperbaiki dan kemudian diketik ulang sebab sebagian besar data yang diperoleh masih belum siap untuk dianalisis karena masih dalam bentuk kasar (catatan lapangan yang masih dalam coret-coretan yang sulit dibaca orang lain, rekaman yang belum ditranskripkan, foto-foto yang belum dicetak atau belum dikelompokkan). Data kualitatif yang banyak itu perlu diperkecil dan dikelompokkan dalam kategori-kategori yang ada. Bahkan dalam analisa data kualitatif, penulis mengaitkan temuantemuan di lapangan dengan teori yang telah ada lalu penulis menginterpretasikan hasil temuan lapangan tersebut ke dalam ranah pemikiran penulis

\section{HASIL DAN PEMBAHASAN}

\section{Kondisi Wilayah Kabupaten}

Anggaran Pendapatan Belanja Daerah Kabupaten Wonosobopada dasarnya merupakan aturan dasar atau hakekat makna dari anggaran yang harus diikuti agar amanat yang diberikan oleh rakyat dapat dicapai dalam rangka meningkatkan kesejahteraan masyarakat pada umumnya.

Di samping itu Bapermades juga melakukan pendampingan terhadap pelaksanaan ADD terhadap desa yang menerima dana tersebut sesuai dengan Peraturan Bupati Wonosobo Nomor 49 Tahun 2010 tentang Pedoman Pelaksanaan Alokasi Dana Desa Kabupaten Wonosobo Tahun 2011. ADD yang dialokasikan untuk Kabupaten Wonosobo pada tahun 2007 Rp 21.228.426.000; tahun $2008 \mathrm{Rp}$ 40.000.000.000; Tahun 2009 sebesar Rp 33.000. 000.000; Tahun 2010 sebesar Rp 27.000.000.000; 
Tabel 1. APBD Kabupaten Wonosobo Tahun 2010

\begin{tabular}{|lll|}
\hline 1. & Pendapatan Daerah & Rp 718.375.340.393 \\
\hline & $\begin{array}{l}\text { 1. Pendapatan Asli Daerah }=\mathrm{Rp} \text { 63.591.324.980 } \\
\text { 2. Dana Perimbangan = Rp 540.506.872.768 } \\
\text { 3. Lain-Lain Pendapatan yang sah = Rp 114.271.142.645 }\end{array}$ \\
\hline 2. & Belanja Daerah & Rp 720.254.292.159 \\
\hline & $\begin{array}{l}\text { 4. Belanja Tidak Langsung = Rp 505.882.831.433 } \\
\text { 5. Belanja Langsung = Rp 214.371.460.726 }\end{array}$ \\
\hline 3. & Pembiayaan & Rp 1.878.951.766 \\
\hline & 1. Penerimaan = Rp 40.469.951.766 & \\
2. Pengeluaran = Rp 38.591.000.000 & \\
\hline
\end{tabular}

Sumber data: Sistem Informasi Profil Daerah Kabupaten Wonosobo Tahun 2010

Dana tersebut dipergunakan untuk kegiatan pembangunan desa dengan perincian sebagai berikut (a) Minimal $30 \%$ untuk kegiatan pengembangan ekonomi kerakyatan dan peningkatan kesejahteraan rakyat; (b) Minimal 30\% untuk kegiatan penyelenggaraan pemerintahan; dan (c) Maksimal $40 \%$ untuk kegiatan pembangunan infrastruktur.

\section{Partisipasi Masyarakat dalam Mengelola ADD di Desa Tegeswetan}

Sebagaimana informasi yang diperoleh dari Kepala Desa Tegeswetan menyebutkan bahwa Desa Tegeswetan menerima ADD sejak tahun 2004. Pemerintah desa selama ini telah melakukan sosialisasi kepada masyarakat melalui kecamatan, seperti menanyakan tentang kesulitan yang dialami oleh masyarakat dan juga sosialisasi mengenai jumlah ADD maupun menempelkan poster-poster ADD pada jalan umum. ADD yang telah digulirkan ke masyarakat selama ini telah bermanfaat dengan baik seperti yang dituturkan oleh Kepala Desa dan masyarakat seperti perbaikan infrastruktur jalan satu kampung yang dibetonisasi dan pembuatan senderan jalan. Hal ini dapat dilihat pada Kadus Kemencing sudah mencapai tahap penyelesaian $100 \%$, Kadus Bojongan sudah mencapai tahap $100 \%$ dan Kadus Sabrang sudah mencapai tahap 100\%, maupun pemberdayaan masyarakat difokuskan untuk kegiatan PKK, bantuan madrasah, pemberdayaan ekonomi seperti simpan pinjam dengan bunga 2,5\%. Jadi keseluruhan ADD dimanfaatkan secara operasional $30 \%$ untuk belanja pegawai, tunjangan BPD, uang representasi $\mathrm{BPD}$, tunjangan $\mathrm{LKMD}$, tunjangan kades, dan $70 \%$ untuk pemberdayaan masyarakat.

Penyaluran ADD telah melibatkan masyarakat dengan baik melalui musrenbangdes, sehingga segala kebutuhan masyarakat dan pembangunan desa dapat dilaksanakan dengan baik melalui ADD. Hal ini bukti bahwa ADD yang berada di Desa Tegeswetan realitanya telah dapat memberdayakan masyarakat. Tak hanya itu masyarakat Desa Tegeswetan juga dilibatkan dalam proses perencanaan, dengan proses awal melalui musyawarah dusun (musdus). Pada forum itu masyarakat diberikan kebebasan untuk menuangkan ide-idenya dan bahkan ada masyarakat yang mengajukan proposal pada saat musyawarah dusun berlangsung.

Dalam hal pengawasan, masyarakat juga dilibatkan meninjau ulang kegiatan ADD karena pemerintah desa bersikap transparan dan akuntabel dalam mengimplementasikan ADD di masyarakat. Selama menjalankan aktivitas kegiatan yang dibiayai ADD, masyarakat melakukannya atas inisiatif sendiri dengan dikoordinir oleh perangkat setempat. Berdasarkan sepengamatan Kepala Desa Tegeswetan sebagai langkah mendukung kelancaran dalam pemanfaatan ADD, pemerintah kabupaten menyelenggarakan pelatihan tentang pelaksanaan ADD yang dilaksanakan di kecamatan. Dana pelatihan tersebut diambil dari dana pendamping setiap tahunnya.

$$
\text { Kepala Desa Tegeswetan juga }
$$
mengungkapkan, selama ini masyarakat telah mengelola dengan baik ADD. Buktinya, kegiatan yang ada baik fisik maupun non fisik tak bisa dilepaskan dari peran serta masyarakat. Bahkan untuk meningkatkan partisipasi masyarakat, semua masyarakat tumbuh kesadaran dan tanggung jawabnya untuk memelihara wilayahnya sendiri tanpa adanya unsur paksaan dari siapapun. Sehingga ADD yang ada sudah layak dan dapat memenuhi kebutuhan mereka dalam membangun desa.

Faktor pendukung yang ditemui masyarakat dalam mengelola ADD adalah pemerintah desa bersikap transparan kepada masyarakat mengenai jumlah ADD yang diterimadari kabupaten dan juga adanya dukungan SDM yang mampu mempersiapkan SPJ dengan tepat waktu. Penyelesaian SPJ tepat waktu merupakan suatu pemberlakukan mengingat apabila SPJ tahap I belum diajukan kepada Bapermasdes maka SPJ tahap kedua tidak akan dicairkan kembali, dan justru SPJ Tahap I merupakan kebenaran administrasi yang semestinya dapat segera dipertanggungjawabkan.

\section{Partisipasi Masyarakat dalam Mengelola ADD di Desa Jangkrikan}

Masyarakat sekitar Desa Jangkrikan menjelaskan bahwa Pemerintah Desa melakukan sosialisasi ADD kepada mereka melalui rapat-rapat musdus dan musdes dengan mengundang masyarakat 
desa dan semua elemen di desa. Masyarakat mengatakan bahwa ADD yang diterima Desa Jangkrikan sangat bermanfaat oleh masyarakat karena sudah sesuai dengan aspirasi masyarakat. Penyaluran ADD berdasarkan informan dari masyarakat telah melibatkan masyarakat dengan baik karena penyaluran sesuai rencana (JOP masing-masing) yang kesemuanya itu atas kerjasama yang baik antara pemerintah desa dan masyarakat. Kronologis penyaluran ADD dijelaskan lebih lanjut oleh kepala desa bahwa setelah menerima uang ADD kemudian pemerintah desa mengundang JOP masing-masing dan melakukan musyawarah di balai desa.

Lebih lanjut informan mengungkapkan kebutuhan masyarakat dan pembangunan desa dapat dilaksanakan dengan baik melalui ADD meski bertahap, karena uang ADD belum langsung mencukupi pembangunan desa seperti pembuatan jalan betonisasi. Oleh karenanya sampai saat ini, dengan proses pencapaian tahap-tahap tertentu ADD dapat berjalan sesuai kesepakatan dalam musyawarah.

Informan masyarakat juga menuturkan dalam pengelolaan ADD didasarkan atas keinisiatifan mereka sendiri dengan memegang asas gotong royong. Di samping itu keterlibatan masyarakat dalam APBDes diterapkan secara terbuka karena menganut prinsip transparansi, sehingga masyarakat mengetahui pengeluaran desa yang tersirat dalam APBDes seperti pengeluaran desa BOP pemerintah desa dan lembagalembaga beserta renovasi untuk infrastruktur fisik. Sejalan pelaksanaan ADD, masyarakat mengungkapkan bahwa ADD telah dilaksanakan dengan baik untuk operasional pemerintah desa sesuai dengan ketentuan yang berlaku.

Informan kepala desa dan masyarakat menjelaskan secara detail, bahwa masyarakat sudah sewajarnya mengetahui pertanggungjawaban ADD, mengingat masyarakat berkecimpung langsung di dalam pengelolaan ADD. Keberhasilan masyarakat dalam berpartisipasi dapat dinilai sebagai wujud turut dilibatkannya masyarakat sampai pada tahap perencanaan. Tahapan perencanaan dimulai dari berbagai gagasan yang dicetus masyarakat yang dilakukan dari musyawarah RT, kadus terus sampai tingkat desa. Dalam mengelola ADD, masyarakat melakukan musyawarah, usulan pertanggungjawaban dan pengawasan terhadap pelaksanaan ADD dengan melibatkan masyarakat langsung, BPD, perangkat desa dan semua unsur desa. Bahkan dengan adanya ADD kesejahteraan masyarakat meningkat karena kebutuhan penunjang dan urgensi bagi masyarakat telah terpenuhi, sekaligus jumlah pengangguran telah menurun. Masyarakat miskin di Desa Jangkrikan juga sudah berangsur berkurang karena mendapat penanganan yang baik.

Pelatihan oleh pemerintah desa maupun pemerintah kabupaten sudah terselenggarakan di aula kecamatan. Berdasarkan informasi dari masyarakat, mereka selama ini ikut memelihara ADD secara baik sesuai dengan keahliannya masing-masing. Adapun faktor pendukung dalam mengelola ADD di Desa Jangkrikan adalah ADD yang bergulir di masyarakat sesuai dengan aspirasi masyarakat sedangkan faktor penghambatnya adalah keterbatasan pada dana yang masih minimalis.

Alokasi Dana Desa merupakan bantuan hibah dari pemerintah daerah yang diperuntukan bagi kemajuan masyarakat desa khususnya dalam memberikan pelayanan kepada masyarakat. Bantuan hibah yang dialokasikan untuk desa tersebut bersumber dari dana APBD yang tentunya disesuaikan dengan kemampuan daerah. ADD yang diprioritaskan untuk kemajuan desa, pada dasarnya mengacu dan menggunakan prinsip-prinsip partisipatif. Bersama masyarakat turun langsung membangun wilayahnya secara swadaya dan bertanggungjawab memperbaiki lingkungannya dengan memegang kebersamaan, saling rasa dan saling karsa.

Secara umum ADD yang diberikan oleh pemerintah daerah wujud menciptakan good governance, yang salah satu karakteristiknya adalah melalui partisipasi. Sebagaimana yang diungkapkan Hetifah Sj. Sumarto (2003) berpendapat salah satu karakteristik dari good governance atau tata kelola pemerintahan yang baik atau kepemerintahan yang baik adalah partisipasi. Bahkan Isbandi Rukminto Adi (2007) menyatakan untuk menciptakan partisipasi aktif masyarakat dalam melaksanakan program pembangunan diperlukan kesadaran warga masyarakat akan minat dan kepentingan yang sama. Strategi yang bisa diterapkan adalah penyadaran. Untuk berhasilnya program tersebut warga masyarakat dituntut untuk terlibat tidak hanya dalam aspek kognitif dan praktis tetapi juga keterlibatan emosional. Seperti yang terjadi di sampel penelitian masyarakat berinsiatif sendiri untuk membangun wilayahnya, karena mereka menganggap bahwa desa tempat mereka mengadu nasib dan tempat bernaung bagi keluarganya. Rasa memiliki yang sangat kuat disamping sifat ke gotong royongan yang melekat dalam diri masyarakat, mengindikasikan pengelolaan ADD berdasarkan prinsip partisipasi melalui perencanaan, pelaksanaan maupun pengawasan telah terlaksana dengan baik. Sebagaimana yang diungkapkan oleh Pusic (2006) bahwa perencanaan tanpa memperhitungkan partisipasi masyarakat akan menjadikan perencanaan hanya di atas kertas. Berdasarkan pandangannya, partisipasi atau keterlibatan warga masyarakat dalam pembangunan desa dapat dilihat dari dua hal yaitu:

1. Partisipasi dalam perencanaan, dapat dilihat dari dua aspek posistif dan negatif. Pada segi positif partisipasi adalah mendorong munculnya keterlibatan secara emosional terhadap programprogram pembangunan desa yang telah direncanakan bersama. Sedangkan negatifnya adalah kemungkinan tidak dapat dihindarinya pertentangan antar kelompok dalam masyarakat yang dapat menunda atau bahkan menghambat tercapainya suatu keputusan bersama. Fakta yang ditemui di lokasi sampel, perencanaan 
ADD masih sebatas beresensi positif dikarenakan perencanaan ADD dilakukan dengan musyawarah untuk mencapai mufakat yang diawali dari kegiatan musyawarah dusun (musdus). Masyarakat diberikan kebebasan untuk menunangkan segala ide-idenya berkaitan kegiatan yang akan direalisasikan. Kesepakatankesepakatan yang terjalin selama musyawarah berlangsung menjadi ketentuan yang harus dijalani bersama, sebab kesepakatan tersebut dapat mempermudah segala aktivitas yang dilaksanakan masyarakat dalam memanfaatkan dana ADD. Kesepakatan tersebut berupa sumbangan dari warga berbentuk material yang secara langsung dapat dimanfaatkan untuk pembangunan jalan. Hal ini terjadi di Desa Jangkrikan Kecamatan Kepil Kabupaten Wonosobo. Beberapa hal yang perlu dijelaskan mengapa perencanaan secara partisipastif bermanfaat yakni (a) Masyarakat mampu secara kritis menilai lingkungan sosial ekonominya dan mampu mengidentifikasi bidang-bidang/atau sektor-sektor yang perlu dilakukan perbaikan, dengan demikian diketahui masa depan mereka terutama yang terjadi di wilayah sampel bahwa jalan-jalan protokol yang perlu perbaikan juga merupakan hasil rekomendasi dari masyarakat; (b) Masyarakat dapat berperan dalam perencanaan masa depan masyarakatnya tanpa memerlukan bantuan para pakar atau instansi perencanaan pembangunan dari luar daerah pedesaan. Masyarakat dapat menghimpun sumber daya dan sumber dana dari kalangan anggota masyarakat untuk mewujudkan tujuan yang dikehendaki masyarakat. Hal ini terjadi di Desa Jangkrikan Kecamatan Kepil Kabupaten Wonosobo dimana masyarakatnya mengumpulkan dana secara swadaya untuk mempercepat pembangunan jalan dengan penarikan iuran perbulan sebesar Rp 100.000 yang dialokasikan untuk kepentingan umum.

2. Partisipasi dalam Pelaksanaan, menurut Isbandi Rukminto Adi (2007) dapat dilihat dari dua segi positif dan negatif. Pada sisi positif, partisipasi adalah bagian terbesar dari suatu program yang dapat menyelesaikan pekerjaaan. Tetapi segi negatifnya adalah kecendrungan yang menjadikan warga masyarakat sebagai objek pembangunan dimana warga hanya dijadikan pelaksana pembangunan tanpa didorong untuk mengerti dan menyadari permasalahan yang mereka hadapi. Sehingga warga masyarakat tidak secara emosional terlibat dalam program, yang berakibat kegagalan seringkali tidak dapat dihindari. Teori ini sepadan dengan realita dilapangan, dimana bila dicermati dari segi positifnya partisipasi di lokasi sampel sangatlah memberi nilai positif yang besar bagi diri masyarakat. Dimana ADD yang dilaksanakan telah relevan dengan kebutuhan masyarakat, karena semua kegiatan yang menggunakan dana ADD dengan berdasarkan aspirasi masyarakat melalui musdus hingga ke musrenbangdes. Bahkan masyarakat sendiri menjadi pelaku majunya pembangunan di desa, dengan kekuatannya sendiri dan tanggungjawab yang dimilikinya sebagai warga desa yang baik tanpa mengenal lelah membuat jalan hingga bermanfaat untuk semua orang terutama dalam hal mendukung perekonomian warga.

Disampaikan lebih lanjut mengapa masyarakat mengetahui kebutuhan desanya sendiri karena beberapa pertimbangan, seperti yang diungkapkan oleh Rahardjo Adisasmita (2006) disebabkan karena (a) Masyarakat memahami sesungguhnya tentang keadaan lingkungan sosial dan ekonomi masyarakatnya; (b) Masyarakat mampu menganalisis sebab dan akibat dari berbagai kejadian yang terjadi dalam masyarakat; (c) Masyarakat mampu merumuskan solusi untuk mengatasi permasalahan dan kendala yang dihadapi masyarakat; (d) Masyarakat mampu memanfaatkan sumber daya pembangunan (SDA, SDM, dana, teknologi) yang dimiliki untuk meningkatkan produksi dan produktivitas dalam rangka mencapai sasaran pembangunan masyarakatnya; dan (e) Masyarakat dengan upayanya meningkatkan kemampuan SDM dan kemauannya sehingga berlandaskan pada kepercayaan diri dan keswadayan yang kuat dan mampu menghilangkan sebagian besar ketergantungannya terhadap pihak luar.

Penelusuran di wilayah sampel mengungkapkan partisipasi masyarakat sangat baik, dikarenakan sebagian besar menganggap desanya adalah sebagai bagian dari rumahnya, dimana masyarakat dilahirkan dan dibesarkan hingga mencari nafkah di desanya. Fenomena ini sepadan dengan yang diungkapkan Anggel bahwa partisipasi yang tumbuh dalam masyarakat dipengaruhi oleh banyak faktor. Faktor-faktor yang mempengaruhi kecenderungan seseorang dalam berpartisipasi, salah satu diantaranya yaitu: Lamanya tinggal, dimana lamanya seseorang tinggal dalam lingkungan tertentu dan pengalamannya berinteraksi dengan lingkungan tersebut akan berpengaruh pada partisipasi seseorang. Semakin lama ia tinggal dalam lingkungan tertentu, maka rasa memiliki terhadap lingkungan cenderung lebih terlihat dalam partisipasinya yang besar dalam setiap kegiatan lingkungan tersebut.

Lain halnya yang diutarakan Holil (1980) unsur-unsur yang mempengaruhi partisipasi sosial yaitu: (a) Kepercayaan diri masyarakat; (b) Solidaritas dan integritas sosial masyarakat; (c) Tanggung jawab sosial dan komitmen masyarakat; (d) Kemauan dan kemampuan untuk mengubah atau memperbaiki keadaan dan membangun atas kekuatan sendiri; (e) Prakarsa masyarakat atau prakarsa perseorangan yang diterima dan diakui sebagai/menjadi milik masyarakat; (f) Kepentingan umum murni, setidaktidaknya umum dalam lingkungan masyarakat yang 
bersangkutan, dalam pengertian bukan kepentingan umum yang semu karena penunggangan oleh kepentingan perseorangan atau sebagian kecil dari masyarakat. Kegiatan ADD yang berjalan memang didasari atas kepentingan umum karena masyarakat yang menentukan dan masyarakat yang mengetahui kebutuhan-kebutuhannya; (g) Musyawarah untuk mufakat dalam pengambilan keputusan dilakukan dengan itikad baik untuk mendapat hasil yang baik. Komitmen menjadi penting tatkala begitu banyak kebutuhan yang mendesak dan menjadi aspirasi masyarakat, namun harus juga dipertimbangkan prioritas yang mendesak dan urgensi untuk realisasikan, dari semua sampel menyatakan bahwa musyawarah mufakat sangatlah penting dalam merencanakan kegiatan ADD; dan (h) Kepekaan dan ketanggapan masyarakat terhadap masalah, kebutuhan-kebutuhan dan kepentingan-kepentingan umum masyarakat. Sikap responsiv masyarakat desa dibuktikan dengan masyarakat atas kesadarannya bahu membahu, bergotong royong berbaur dengan masyarakat lainnya untuk mencapai satu tujuan yaitu menciptakan iklim kegotongroyongan, tanpa memandang harkat dan martabat tapi mencapai misi kemajuan pembangunan secara harfiah.

Sejalan perkembangannya, masyarakat dalam mengelola ADD juga dihadapkan faktor penghambat diantaranya adalah keterbatasan dana ADD yang tidak bisa mengakomodir kebutuhan masyarakat. Faktor pendukung yang ditemui masyarakat diantaranya adalah koordinasi dan komunikatif yang erat antara Pemerintah Desa dengan masyarakat, transparansi pemerintah desa dalam melaporkan pertanggungjawaban ADD, sinkronisasi antara aspirasi masyarakat dengan kegiatan ADD. Holil berpandangan Implikasinya dapat dilihat dari beberapa faktor, yang berasal dari luar diri masyarakat diantaranya dipengaruhi oleh (1) Komunikasi yang intensif antara sesama warga masyarakat, antara warga masyarakat dengan pimpinannya serta antara sistem sosial di dalam masyarakat dengan sistem di luarnya; dan (2) Kebebasan untuk berprakarsa dan berkreasi. Lingkungan di dalam keluarga masyarakat atau lingkungan politik, sosial, budaya yang memungkinkan dan mendorong timbul dan berkembangnya prakarsa, gagasan, perseorangan atau kelompok.

Dengan demikian peranan pemerintah daerah maupun pemerintah desa adalah merencanakan dan mengorganisir program ADD dengan menyediakan bantuan tehnis dan bantuan bahan-bahan pokok, diluar kemampuan masyarakat setempat dan organisasiorganisasi non pemerintah lainnya. Oleh karenanya partisipasi masyarakat menjadi elemen yang penting dalam pengembangan masyarakat desa, mengingat masyarakat yang memahami dan mengerti kondisi lingkungannya. Berdasarkan pemantauan di lapangan, ADD yang telah bergulir di masyarakat secara implisit bermanfaat bagi masyarakat diantaranya adalah: (a) Desa dapat menghemat biaya pembangunan, karena desa dapat mengelola sendiri proyek pembangunannya dan hasil-hasilnya dapat dipelihara secara baik demi keberlanjutannya. Seperti yang diketahui bahwa masyarakat desa yang memperhitungkan sendiri pengeluaran untuk pembangunan fisik, tanpa mencari keuntungan masyarakat mengalokasikan sebesarbesarnya dana yang ada untuk perbaikan jalan. Bahkan tenaga masyarakat dengan sukarela dipertaruhkan demi kepentingan bersama, tanpa mengenal lelah dan waktu masyarakat menyelesaikan pekerjaan jalan yang dilakukannya saat ini; (b) Tiaptiap desa memperoleh pemerataan pembangunan sehingga lebih mampu memberikan pelayanan kepada masyarakat desa, disebabkan pembangunan di desadesa sampai dusun-dusun sudah mengalami perubahan, jalan becek telah di betonisasi, masyarakat dengan mudah mengakses jalan dengan mengendarai kendaraan roda empat atau roda dua; (c) Desa memperoleh kepastian anggaran untuk belanja operasional pemerintahan desa. Sebelum adanya ADD, belanja operasional pemerintahan desa besarnya tidak pasti. Karena dalam ketentuannya sudah dijelaskan 30\% untuk operasional Pemerintah Desa dan $70 \%$ untuk pemberdayaan masyarakat;(d) Desa dapat menangani permasalahan desa secara cepat tanpa harus lama menunggu datangnya program dari pemerintah daerah Kabupaten/Kota; (e) Desa tidak lagi hanya tergantung pada swadaya masyarakat dalam mengelola persoalan pemerintahan, pembangunan serta sosial kemasyarakat desa; (f) Dapat mendorong terciptanya demokrasi di desa. ADD dapat melatih masyarakat dan pemerintah desa untuk bekerjasama, memunculkan kepercayaan antar pemerintah desa dengan masyarakat desa dan mendorong adanya kesukarelaan masyarakat desa untuk membangun dan memelihara desanya; dan $(\mathrm{g})$ Dapat mendorong terciptanya pengawasan langsung dari dari masyarakat untuk menekan terjadinya penyimpangan. Hal ini terjadi di Desa Tegeswetan Kecamatan Kepil Kabupaten Wonosobo, bahwa masyarakat bergerak kritis dan segera melaporkan kepada pemerintah daerah dalam hal ini Bapermasdes apabila ditemui penyimpangan yang dilakukan oleh kepala desa. Seperti yang dilaporkan masyarakat terkait kepala desa yang melakukan penggelapan dana ADD sekitar Rp 10.000.000, atas pelaporan masyarakat tersebut hingga saat ini kepala desa dikenai tindakan pidana 2 tahun penjara.

Menurut Bahrul Ulum partisipasi masyarakat dalam mengelola ADD adalah hak bagi warga untuk menyuarakan, mengakses, mengontrol program ADD yang ada di desanya. Sedangkan dampak dari tingginya kepercayaan masyarakat terhadap program tersebut disebut swadaya. Pengelolaan ADD harus menyatu di dalam pengelolaan APBDes, sehingga prinsip pengelolaan ADD sama persis dengan pengelolaan APBDes yang harus mengikuti prinsipprinsip good governance yaitu (a) Partisipatif, proses pengelolaan ADD sejak perencanaan, pengambilan keputusan sampai dengan pengawasan serta evaluasi 
harus melibatkan banyak pihak. Artinya dalam mengelola ADD tidak hanya melibatkan para elit saja tetapi juga harus melibatkan masyarakat lain seperti petani, kaum buruh, masyarakat, dll. Sedari awal di lokasi sampel partisipasi menjadi tolak ukur keberhasilan ADD, tanpa masyarakat ADD tidak dapat terealisasi dengan sempurna, dan tanpa masyarakat pula ADD tidak bermanfaat apapun; (b) Transparan, semua pihak dapat mengetahui keseluruhan proses secara terbuka. Selain itu diupayakan agar masyarakat desa dapat menerima informasi mengenai tujuan, sasaran, hasil, manfaat yang diperolehnya dari setiap kegiatan yang menggunakan dana ini. Sikap transparansi di lokasi sampel sudah diterapkan oleh Pemerintah Desa kepada masyarakat, bahkan masyarakat mengetahuinya melalui poster penggumuman tentang ADD yang memuat kegiatan-kegiatan ADD sekaligus pertanggungjawaban SPJ ADD juga diketahui khalayak yang diinfokan melalui Musrenbangdes; dan (c) Akuntabel, keseluruhan proses penggunaan ADD mulai dari usulan peruntukkannya, pelaksanaan sampai dengan pencapaian hasilnya dapat dipertanggungjawabkan di depan seluruh pihak terutama masyarakat desa.

Sehubungan dengan itu, seyogyanyalah partisipasi masyarakat menjadi faktor utama pendukung keberhasilan ADD. Masyarakat penggerak terciptanya akselerasi pembangunan masyarakat desa, di tangan masyarakatlah maju mundurnya desa menjadi prinsip yang harus dipahami oleh stakeholder di desa. Dengan mengeyampingkan kepentingankepentingan pribadi dan egosentris pemangku kebijakan desa dan menomorsatukan masyarakat di atas segala-galanya, menjadikan cita-cita luhur untuk meningkatkan kesejahteraan masyarakat menjadi sesuatu yang urgen untuk ditindaklanjuti dan ditingkatkan. Oleh karenanya, partisipasi masyarakat menjadi langkah kongkrit terwujudnya kemakmuran dan peningkatan kesejahteraan secara parsial.

\section{SIMPULAN}

Menyimak uraian-uraian di atas, dapat disimpulkan beberapa hal sebagai berikut (1) Tingkat partisipasi masyarakat Desa Tegeswetan dan Desa Jangkrikan dapat dilihat pada tahap perencanaan, pelaksanaan maupun pengawasan yang tergolong sangat baik. (2) Faktor pendukung dan penghambat diantaranya yaitu (a) Dukungan dari Pemerintah Kabupaten dan Pemerintah Desa yang berkooperatif dan komunikasi efektif dalam meregulasikan ADD di wilayah Desa Tegeswetan dan Desa Jangkrikan sehingga pelaporan pertanggungjawaban dapat dilaporkan dengan waktu yang telah ditentukan; (b) Partisipasi masyarakat meningkat karena kesadaran untuk membangun desa telah tertanam dari dalam diri mereka untuk berkontribusi dalam pengelolaan ADD; (c) Sikap mental Pemerintah desa yang transparan, akuntabel dalam memanfaatkan dana ADD; (d)
Masyarakat kritis dalam mengawasi pelaksanaan ADD sehingga meminimalisir terjadinya penyelewengan dana ADD; dan (e) minimnya ketersediaan dana ADD yang tidak semuanya dapat mengakomodir kebutuhan masyarakat desa.

Berdasarkan simpulan di atas, disarankan (1) Hendaknya pemanfaatan ADD tidak hanya difokuskan untuk pembangunan fisik semata, karena banyak aspek lainnya yang perlu menjadi atensi semua pihak; (2) Masyarakat perludilibatkan dalam pembuatan SPJ, mengingat di sekitar desa banyak masyarakat yang berpotensi dan memiliki latar belakang pendidikan yang memadai dan mampu diberdayakan secara maksimal dalam proses pembuatan laporan. (3) Menambah anggaran ADD dari yang semestinya, mengingat ADD sangat bermanfaat untuk kemajuan pembangunan desa; (4) Masyarakat yang terlibat dalam pengelolaan ADD perlu mendapat pengawasan dari pemerintah desa.

\section{DAFTAR PUSTAKA}

Conyers, Diana. 1991. Perencanaan Sosial di Dunia Ketiga. Yogyakarta: UGM Press.

Hetifah Sj. Sumarto. 2003. Inovasi, Partisipasi dan Good Governance. Jakarta: Yayasan Obor Indonesia.

Holil Soelaiman. 1980. Partisipasi Sosial dalam Usaha Kesejahteraan Sosial. Bandung.

Isbandi Rukminto Adi. 2007. Perencanaan Partisipatoris Berbasis Aset Komunitas: dari Pemikiran Menuju Penerapan. Depok: FISIP UI Press.

Mikkelsen, Britha. 1999. Metode Penelitian Partisipatoris dan Upaya-upaya Pemberdayaan: Sebuah Buku Pegangan Bagi Para Praktisi Lapangan. Jakarta: Yayasan Obor Indonesia.

Rahardjo Adisasmita. 2006. Membangun Desa Partisipatif. Yogyakarta: Graha Ilmu.

Suharsimi, Arikunto. 2003. Manajemen Penelitian. Cet. Ke-IV. Jakarta: PT. Rineka Cipta.

Akuntabilitas Pengelolaan Dana Desa (Studi Kasus Pengelolaan Alokasi Dana Desa di Desa-Desa dalam Wilayah Kecamatan Tlogomulyo Kabupaten Temanggung Tahun 2008). http://eprints.undip.ac.id/7610/1/Agus Subroto.pdf.

http://pemdeswonosobo.blogspot.com/2009/04/alokasidana-desa.html.

http://www.forumdesa.org/download/buku_saku_add/ buku_saku_ADD.pdf 
188 | Jurnal Bina Praja | Volume 4 No. 3 September 2012| 179 - 188 